\title{
Students' Phubbing in Rural University Classrooms: Are They Crossing Boundaries? Academics' Perceptions
}

\author{
Simon Christopher Fernandez ${ }^{1, *}$, John Percival Fernandez ${ }^{2}$ \\ ${ }^{1}$ Faculty of Science, Engineering and Technology, Walter Sisulu University, East London, South Africa \\ ${ }^{2}$ Faculty of Business Science \& Management, Walter Sisulu University, East London, South Africa
}

Received May 15, 2021; Revised June 28, 2021; Accepted July 19, 2021

\begin{abstract}
Cite This Paper in the following Citation Styles
(a): [1] Simon Christopher Fernandez, John Percival Fernandez, "Students' Phubbing in Rural University Classrooms: Are They Crossing Boundaries? Academics' Perceptions" Universal Journal of Educational Research, Vol. 9, No. 8, pp. 1599 - 1609, 2021. DOI: 10.13189/ujer.2021.090812.
\end{abstract}

(b): Simon Christopher Fernandez, John Percival Fernandez (2021). Students' Phubbing in Rural University Classrooms: Are They Crossing Boundaries? Academics' Perceptions. Universal Journal of Educational Research, 9(8), 1599 - 1609. DOI: 10.13189/ujer.2021.090812.

Copyright $\odot 2021$ by authors, all rights reserved. Authors agree that this article remains permanently open access under the terms of the Creative Commons Attribution License 4.0 International License

\begin{abstract}
The current study sought to establish perceptions of lecturers and Peer Assistant Learning (PAL) Tutors on students' phubbing at a rural university in the Eastern Cape Province of South Africa. The study adopted the quantitative approach in which a survey was employed. A sample of 50 academics that consisted of 39 lecturers from a population of 71 and 11 PAL Tutors from a population of 14 voluntarily completed the survey. A structured 5-point Likert scale questionnaire was used for the data collection. The researchers captured the data manually into Statistical Package for Social Sciences and they were analysed using descriptive statistics. The study found that majority of lecturers and PAL Tutors had a negative perception on students' phubbing in classroom. It was strongly confirmed that students were addicted to cell phones. Around $0 \%-20 \%$ of the students were phubbing by doing different activities in classroom which was more enough for the whole learning and teaching to be spoiled. Overall, phubbing created a serious interruption to lecturers, PAL Tutors as well as the whole class and this implicated the study to highlight that students were crossing the boundary line. This study also provided recommendations to the educators and management to minimize phubbing inside classroom.
\end{abstract}

Keywords Phubbing, Smart Phone, Cell Phone, Educational Technology, Mobile Technology, Rural University Education, Lecturers, Peer Assisted Learning Tutors

\section{Introduction}

The daily developments of technologies ubiquitously have become very common. Among them, the impact of cell phones on the life of common people especially in youngsters has been proliferated remarkably. According to Global System for Mobile Communications (GSMA) Intelligence [1], the number of cell phone connections including the licensed cellular all over the world has crossed over 8 billion. Almost half of the total population in the world are currently using internet through their smart phones, which is a massive increase of 250 million users since the end of 2018 [2]. South Africa is not an exception in this regard. South Africa is the second biggest mobile market in the African continent with 37.5 million unique mobile subscribers and more than 80 million connections as most of the people have multiple SIM cards across various networks [3]. There was an increase of 3.1 million of cell phone connections in South Africa between January 2019 and January 2020 [4]. Beger and Sinha [5] highlighted that $72 \%$ of South African adolescents between the age of 15 and 24 use cell phones. According to the report of CNN, between 2007 and 2014 the ownership of cell phones among adolescents in South Africa climbed up from $21 \%$ to $50.8 \%$ [6].

Despite students in this generation are fast in familiarizing with the features of mobile technologies, they also spend much of their valuable time for non-academic purposes such as being in internet to socialize $[7,8]$ to play games, to send and receive 
messages and calls $[9,10]$. Majority of university students use at least one cell phone [11]. They are using smart phones while they are doing their homework [12], studying [13] and even while attending lectures in classroom $[14,15]$. A study conducted in the United States of America by Junco [16] stated that students are using facebook for nearly 100 minutes per day. Lepp, Barkley and Karpinski [17] highlighted that college students are using cell phones for almost five hours per day. Another study conducted by Wentworth and Middleton [18] showed that students were sending more than 150 messages per day. The phenomenon of ignoring or snubbing someone by actively involving in cell phones or smart phones instead of concentrating to that person is called Phubbing [19, 20, 21].

Phubbing is a combination of "phone" and "snub" [22]. Although the word Phubbing is a brand new educational term, students' use of phones in classroom is not new. The studies based on students' phubbing in university classrooms are scarce $[19,23]$ especially in South Africa and that too from the perception of lecturers and PAL Tutors. PAL Tutors are the senior students who are expert in the subject field. They are appointed or employed by the Centre of learning and teaching department of the university for the subjects that has a high failure rate to assist the lecturers. PAL Tutors will be lecturing their junior students in the evening after the normal class hours of lecturers. Due to the high penetration rate in the use of cell phones, regular updates in this area of study are a vital factor. Therefore, the purpose of this study was to understand the perceptions of lecturers and PAL Tutors on students' phubbing at a rural university in the Eastern Cape Province of South Africa. The key research questions of this study were:

1. What are the perceptions of lecturers and PAL Tutors on students' phubbing in rural university classrooms?

2. How many students phub in rural university classrooms?

\section{Literature Review}

A very recent study conducted at Pamukkale University in Turkey examined the status of in-service and pre-service teachers of being phubee and phubber. A sample of 247 pre-service teachers and 46 in-service teachers were selected using convenience sampling technique. A seven-point Likert scale questionnaire was used for the study to collect data. Findings revealed that pre-service teachers were more in the case of being both phubbee $(\bar{x}$ Pre-service teacher $=79.65>\bar{x} I n$-service teacher $=72.89)$ and phubber ( $\overline{\mathrm{x}}$ Pre-service teacher $=$ $43.54>\bar{x} I n$-service teacher $=38.39)$ compared with the in-service teachers [24].

Shrivastava and Shrivastava [25] conducted a research in Oman to explore the perceptions of lecturers on students' use of cell phones in classroom. A total of 32 lecturers from different colleges and universities have participated in the survey. A five-point Likert scale questionnaire that consisted of 15 items was sent to all participants online to collect the data. Findings showed that cell phones have a strong influence on distracting learning and teaching. The lecturers also reported that students were misbehaving in class while using cell phones and losing focus which created a high level of stress among lecturers.

Another study was conducted in the Eastern Region of United States of America to explore the perceptions of faculties in different ranks on the effects of students' use of smart phones in classroom. A mixed method approach was employed for the study. A sample of 134 faculty members from various colleges at a local university responded to a five-point Likert scale questionnaire that comprised of 15 questions. As there was a lack of clarity in the data obtained through closed-ended survey, the researchers conducted one-on-one interview with eight participants for a detailed explanation to supplement the numerical data obtained from the survey. Results specified that majority of the faculties complained about the distractions even though strict policies were taken. However, a few faculties used smart phones as a pedagogical tool and obtained positive results [26]. Similarly, Bugeja [27] stated that some instructors agreed that along with the positive side of technologies, it also caused distractions in classroom.

Nazir [28] studied about the students' behavior and attitudes towards phubbing. The study employed a mixed method approach in which a survey was conducted first to collect the data from students and thereafter followed by the interviews to collect the data from lecturers. A sample of 50 lecturers and 300 students from different private universities of Istanbul participated in the study. The findings revealed that around $41 \%$ of the students were phubbing in the classroom while the lecture was taking place and it was negatively affecting the whole learning process.

Furthermore, another research was conducted to examine the behavior of cyber slacking among students in college classrooms and to determine what college instructors can do about students cyber slacking. Usage of cell phones for off-task behaviors in the classrooms is called as cyber slacking. The researchers conducted this study by considering the experiences of a biology lecturer Dr. Sousa and an undergraduate student Eric. The results showed that Eric and other students had high tendency to check the incoming messages and reply during the lecture time and outside the classrooms while they were studying. This temptation of cyber slacking in the class hours has led students to lose focus and obtain less marks for the assessments [29]. Likewise, responses of professors in the study conducted by Lawson and Henderson [15] reported that it was impossible for professors to control students in 
texting during class.

Contrary to the above studies, a research conducted by Ahmad [30] explored the views of a lecturer on undergraduate students' use of cell phones in the learning environment and more particularly to find out whether cell phones were creating any kind of distraction. The survey was conducted at the University of the West Indies, Mona Campus, Jamaica. It can be observed from the study that there was no distraction due to the students' use of cell phones in classroom. Moreover, the lecturer in this experiment enjoyed students' use of cell phones as it helped them to gather relevant information.

\section{Materials and Methods}

\subsection{Research Approach and Design}

The study adopted a quantitative research approach as it allowed for a greater objectivity and accuracy of results. A descriptive research design was implemented for this study as it gave a holistic understanding of the research objective.

\subsection{Study Site, Population and Sample}

A sample of 50 academics that consisted of 39 lecturers from a population of 71 and 11 PAL Tutors from a population of 14 voluntarily participated in the survey. Data of lecturers were collected from the Faculty of Science, Engineering \& Technology and Faculty of Business Science \& Management at a rural university located in the Eastern Cape State of South Africa. The main reason for choosing this rural university as the study site was based on the convenience of the researchers as they both were working as lecturers in the same university. There were no policies to follow in the university to restrict students' phubbing in classroom. As both the faculties were on the same campus of the researchers, the researchers had the contact details of the lecturers and PAL Tutors in the faculties which made the justification for choosing the aforementioned faculties. Moreover, data of PAL Tutors were collected only from the Faculty of Science, Engineering \& Technology as the PAL Tutors from other faculties were not available during the time of data collection. PAL Tutors also do the same job of lecturers in terms of teaching. Students' phub during the lecture hours of lecturers and PAL Tutors. This made the justification of including PAL Tutors as the participants along with lecturers.

\subsection{Data Collection Instrument}

A five-point Likert-scale questionnaire was used as an instrument for data collection which was developed by the researchers themselves. It was categorized into three sections that included demographic, students' use of cell phones in classrooms and the number of students who use cell phones for off-task behaviors. The second section included 15 statements ranged from level 1 to level 5 with level 1 being "STRONGLY DISAGREE", level 2 being "DISAGREE", level 3 being "NO OPINION", level 4 being "AGREE" and level 5 being "STRONGLY AGREE". The third section included six statements ranged from level 1 to level 5 with level 1 being $0 \%$ $20 \%$, level 2 being $21 \%$ - $40 \%$, level 3 being $41 \%-60 \%$, level 4 being $61 \%-80 \%$ and level 5 being $81 \%-100 \%$.

\subsection{Ethical Clearances}

Ethical issues were cleared by obtaining permission from the relevant authorities to conduct the study. Participants gave their permission to collect the data by reading the ethical concerns which was explained on the home page of the survey and participated in the study.

\subsection{Pilot Study}

The study was piloted with five lecturers who were not involved in the main study. Cronbach's alpha test was performed to calculate the reliability of the statements in the questionnaire and reliability values of second section and third section were 0.795 and 0.7 respectively which was appropriate for this study.

\subsection{Data Collection Procedure}

The researchers entered the statements in Google form. As the researchers were having the contact details of participants, the web link of the Google form was sent to the participants through email and WhatsApp. The participants were directed to the survey once they clicked on the web link where they could see the purpose of the research and informed consent form. It was also emphasized that their participation was voluntary, the data collected from them would be kept confidential and anonymous. When the participants agreed to participate, they were directed to the first section which was the demographic page. The response rates of lecturers and PAL Tutors were $54 \%$ and $79 \%$ respectively. The survey was open to the participants from 28-07-2020 $12 \mathrm{AM}$ to 05-08-2020 11.59 PM.

\subsection{Data Analysis}

The researchers captured the data manually into Statistical Package for Social Sciences (SPSS version 26) and they were analysed using descriptive statistics. Furthermore, findings were confirmed using triangulation by sources. 


\section{Results}

Table 1. Triangulation of descriptive statistics of lecturers' perceptions on students' phubbing in university classroom

\begin{tabular}{|c|c|c|c|c|c|c|c|c|}
\hline STATEMENT & \# & SD & $\mathrm{D}$ & NO & A & SA & $\mathrm{N}$ & NA \\
\hline \multirow{2}{*}{$\begin{array}{l}\text { Students don't switch off or keep in silent mode } \\
\text { their cell phones during my lecture hours. }\end{array}$} & L1 & $\begin{array}{c}0 \\
(0 \%)\end{array}$ & $\begin{array}{c}8 \\
(20.5 \%)\end{array}$ & $\begin{array}{c}1 \\
(2.6 \%)\end{array}$ & $\begin{array}{c}21 \\
(53.8 \%)\end{array}$ & $\begin{array}{c}9 \\
(23.1 \%)\end{array}$ & $\begin{array}{c}39 \\
(100 \%)\end{array}$ & 0 \\
\hline & $\mathrm{P} 1$ & $\begin{array}{c}1 \\
(9 \%) \\
\end{array}$ & $\begin{array}{c}2 \\
(18.2 \%) \\
\end{array}$ & $\begin{array}{c}2 \\
(18.2 \%) \\
\end{array}$ & $\begin{array}{c}3 \\
(27.3 \%) \\
\end{array}$ & $\begin{array}{c}3 \\
(27.3 \%) \\
\end{array}$ & $\begin{array}{c}11 \\
(100 \%) \\
\end{array}$ & 0 \\
\hline \multirow{2}{*}{$\begin{array}{l}\text { The whole class and I get interrupted when cell } \\
\text { phones ring in the classroom. }\end{array}$} & $\mathrm{L} 2$ & $\begin{array}{c}1 \\
(2.6 \%) \\
\end{array}$ & $\begin{array}{c}3 \\
(7.7 \%) \\
\end{array}$ & $\begin{array}{c}3 \\
(7.7 \%) \\
\end{array}$ & $\begin{array}{c}16 \\
(41 \%) \\
\end{array}$ & $\begin{array}{c}16 \\
(41 \%) \\
\end{array}$ & $\begin{array}{c}39 \\
(100 \%) \\
\end{array}$ & 0 \\
\hline & $\mathrm{P} 2$ & $\begin{array}{c}0 \\
(0 \%)\end{array}$ & $\begin{array}{c}1 \\
(9.1 \%)\end{array}$ & $\begin{array}{c}0 \\
(0 \%)\end{array}$ & $\begin{array}{c}4 \\
(36.4 \%)\end{array}$ & $\begin{array}{c}6 \\
(54.5 \%)\end{array}$ & $\begin{array}{c}11 \\
(100 \%)\end{array}$ & 0 \\
\hline \multirow{2}{*}{$\begin{array}{l}\text { I do not allow students to attend phone calls in } \\
\text { classroom. }\end{array}$} & L3 & $\begin{array}{c}1 \\
(2.6 \%) \\
\end{array}$ & $\begin{array}{c}8 \\
(20.5 \%)\end{array}$ & $\begin{array}{c}2 \\
(5.1 \%) \\
\end{array}$ & $\begin{array}{c}13 \\
(33.3 \%) \\
\end{array}$ & $\begin{array}{c}15 \\
(38.5 \%) \\
\end{array}$ & $\begin{array}{c}39 \\
(100 \%) \\
\end{array}$ & 0 \\
\hline & P3 & $\begin{array}{c}1 \\
(9.1 \%)\end{array}$ & $\begin{array}{c}3 \\
(27.3 \%)\end{array}$ & $\begin{array}{c}4 \\
(36.3 \%)\end{array}$ & $\begin{array}{c}2 \\
(18.2 \%)\end{array}$ & $\begin{array}{c}1 \\
(9.1 \%)\end{array}$ & $\begin{array}{c}11 \\
(100 \%)\end{array}$ & 0 \\
\hline \multirow{2}{*}{$\begin{array}{c}\text { I give permission to students to leave the } \\
\text { classroom and attend the calls if it is an } \\
\text { emergency. }\end{array}$} & L4 & $\begin{array}{c}6 \\
(15.4 \%) \\
\end{array}$ & $\begin{array}{c}2 \\
(5.1 \%) \\
\end{array}$ & $\begin{array}{c}6 \\
(15.4 \%) \\
\end{array}$ & $\begin{array}{c}17 \\
(43.6 \%) \\
\end{array}$ & $\begin{array}{c}8 \\
(20.5 \%) \\
\end{array}$ & $\begin{array}{c}39 \\
(100 \%) \\
\end{array}$ & 0 \\
\hline & P4 & $\begin{array}{c}0 \\
(0 \%) \\
\end{array}$ & $\begin{array}{c}0 \\
(0 \%) \\
\end{array}$ & $\begin{array}{c}1 \\
(9.1 \%) \\
\end{array}$ & $\begin{array}{c}6 \\
(54.5 \%) \\
\end{array}$ & $\begin{array}{c}4 \\
(36.4 \%) \\
\end{array}$ & $\begin{array}{c}11 \\
(100 \%) \\
\end{array}$ & 0 \\
\hline \multirow{2}{*}{ Students' text during lecture time. } & L5 & $\begin{array}{c}2 \\
(5.1 \%)\end{array}$ & $\begin{array}{c}7 \\
(17.9 \%)\end{array}$ & $\begin{array}{c}6 \\
(15.4 \%)\end{array}$ & $\begin{array}{c}21 \\
(53.9 \%)\end{array}$ & $\begin{array}{c}3 \\
(7.7 \%)\end{array}$ & $\begin{array}{c}39 \\
(100 \%)\end{array}$ & 0 \\
\hline & P5 & $\begin{array}{c}0 \\
(0 \%)\end{array}$ & $\begin{array}{c}3 \\
(27.3 \%)\end{array}$ & $\begin{array}{c}0 \\
(0 \%)\end{array}$ & $\begin{array}{c}3 \\
(27.3 \%)\end{array}$ & $\begin{array}{c}5 \\
(45.4 \%)\end{array}$ & $\begin{array}{c}11 \\
(100 \%)\end{array}$ & 0 \\
\hline \multirow{2}{*}{ Students make calls during lecture time. } & L6 & $\begin{array}{c}16 \\
(41 \%) \\
\end{array}$ & $\begin{array}{c}17 \\
(43.6 \%) \\
\end{array}$ & $\begin{array}{c}2 \\
(5.1 \%) \\
\end{array}$ & $\begin{array}{c}4 \\
(10.3 \%) \\
\end{array}$ & $\begin{array}{c}0 \\
(0 \%) \\
\end{array}$ & $\begin{array}{c}39 \\
(100 \%) \\
\end{array}$ & 0 \\
\hline & P6 & $\begin{array}{c}1 \\
(11.2 \%) \\
\end{array}$ & $\begin{array}{c}2 \\
(22.2 \%) \\
\end{array}$ & $\begin{array}{c}3 \\
(33.3 \%) \\
\end{array}$ & $\begin{array}{c}3 \\
(33.3 \%) \\
\end{array}$ & $\begin{array}{c}0 \\
(0 \%) \\
\end{array}$ & $\begin{array}{c}9 \\
(100 \%) \\
\end{array}$ & 2 \\
\hline \multirow{2}{*}{$\begin{array}{l}\text { Students play games on cell phones during my } \\
\text { lecture period. }\end{array}$} & L7 & $\begin{array}{c}6 \\
(15.4 \%)\end{array}$ & $\begin{array}{c}15 \\
(38.5 \%)\end{array}$ & $\begin{array}{c}9 \\
(23.1 \%)\end{array}$ & $\begin{array}{c}8 \\
(20.5 \%)\end{array}$ & $\begin{array}{c}1 \\
(2.5 \%)\end{array}$ & $\begin{array}{c}39 \\
(100 \%)\end{array}$ & 0 \\
\hline & P7 & $\begin{array}{c}3 \\
(27.3 \%)\end{array}$ & $\begin{array}{c}2 \\
(18.2 \%)\end{array}$ & $\begin{array}{c}4 \\
(36.4 \%)\end{array}$ & $\begin{array}{c}2 \\
(18.1 \%)\end{array}$ & $\begin{array}{c}0 \\
(0 \%)\end{array}$ & $\begin{array}{c}11 \\
(100 \%)\end{array}$ & 0 \\
\hline \multirow{2}{*}{$\begin{array}{l}\text { Students have a temptation to be connected to } \\
\text { social networking sites such as facebook, } \\
\text { twitter and youtube during my lecture time. }\end{array}$} & L8 & $\begin{array}{c}3 \\
(7.7 \%) \\
\end{array}$ & $\begin{array}{c}6 \\
(15.4 \%) \\
\end{array}$ & $\begin{array}{c}8 \\
(20.5 \%) \\
\end{array}$ & $\begin{array}{c}16 \\
(41 \%) \\
\end{array}$ & $\begin{array}{c}6 \\
(15.4 \%) \\
\end{array}$ & $\begin{array}{c}39 \\
(100 \%) \\
\end{array}$ & 0 \\
\hline & P8 & $\begin{array}{c}0 \\
(0 \%) \\
\end{array}$ & $\begin{array}{c}2 \\
(18.2 \%) \\
\end{array}$ & $\begin{array}{c}0 \\
(0 \%) \\
\end{array}$ & $\begin{array}{c}3 \\
(27.3 \%) \\
\end{array}$ & $\begin{array}{c}6 \\
(54.5 \%) \\
\end{array}$ & $\begin{array}{c}11 \\
(100 \%)\end{array}$ & 0 \\
\hline \multirow{2}{*}{$\begin{array}{l}\text { Students get distracted when their classmates } \\
\text { use cell phones in the class room. }\end{array}$} & L9 & $\begin{array}{c}1 \\
(2.6 \%) \\
\end{array}$ & $\begin{array}{c}0 \\
(0 \%) \\
\end{array}$ & $\begin{array}{c}3 \\
(7.7 \%) \\
\end{array}$ & $\begin{array}{c}28 \\
(71.8 \%) \\
\end{array}$ & $\begin{array}{c}7 \\
(17.9 \%) \\
\end{array}$ & $\begin{array}{c}39 \\
(100 \%) \\
\end{array}$ & 0 \\
\hline & P9 & $\begin{array}{c}0 \\
(0 \%) \\
\end{array}$ & $\begin{array}{c}0 \\
(0 \%) \\
\end{array}$ & $\begin{array}{c}1 \\
(9.1 \%) \\
\end{array}$ & $\begin{array}{c}6 \\
(54.5 \%) \\
\end{array}$ & $\begin{array}{c}4 \\
(36.4 \%) \\
\end{array}$ & $\begin{array}{c}11 \\
(100 \%) \\
\end{array}$ & 0 \\
\hline \multirow{2}{*}{$\begin{array}{l}\text { Students immediately use their cell phones } \\
\text { whenever I give them a small break. }\end{array}$} & L10 & $\begin{array}{c}2 \\
(5.1 \%) \\
\end{array}$ & $\begin{array}{c}3 \\
(7.7 \%) \\
\end{array}$ & $\begin{array}{c}4 \\
(10.3 \%) \\
\end{array}$ & $\begin{array}{c}20 \\
(51.3 \%) \\
\end{array}$ & $\begin{array}{c}10 \\
(25.6 \%) \\
\end{array}$ & $\begin{array}{c}39 \\
(100 \%) \\
\end{array}$ & 0 \\
\hline & $\mathrm{P} 10$ & $\begin{array}{c}0 \\
(0 \%)\end{array}$ & $\begin{array}{c}0 \\
(0 \%)\end{array}$ & $\begin{array}{c}1 \\
(9.1 \%)\end{array}$ & $\begin{array}{c}4 \\
(36.4 \%) \\
\end{array}$ & $\begin{array}{c}6 \\
(54.5 \%) \\
\end{array}$ & $\begin{array}{c}11 \\
(100 \%)\end{array}$ & 0 \\
\hline \multirow{2}{*}{ I feel students are addicted to cell phones. } & L11 & $\begin{array}{c}5 \\
(13.2 \%) \\
\end{array}$ & $\begin{array}{c}2 \\
(5.3 \%)\end{array}$ & $\begin{array}{c}3 \\
(7.9 \%)\end{array}$ & $\begin{array}{c}14 \\
(36.8 \%)\end{array}$ & $\begin{array}{c}14 \\
(36.8 \%)\end{array}$ & $\begin{array}{c}38 \\
(100 \%)\end{array}$ & 1 \\
\hline & $\mathrm{P} 11$ & $\begin{array}{c}1 \\
(9.1 \%)\end{array}$ & $\begin{array}{c}0 \\
(0 \%)\end{array}$ & $\begin{array}{c}1 \\
(9.1 \%)\end{array}$ & $\begin{array}{c}2 \\
(18.2 \%)\end{array}$ & $\begin{array}{c}7 \\
(63.6 \%)\end{array}$ & $\begin{array}{c}11 \\
(100 \%)\end{array}$ & 0 \\
\hline \multirow{2}{*}{$\begin{array}{l}\text { Students are lazy to write notes after they } \\
\text { started using cell phones. }\end{array}$} & L12 & $\begin{array}{c}2 \\
(5.1 \%) \\
\end{array}$ & $\begin{array}{c}11 \\
(28.2 \%) \\
\end{array}$ & $\begin{array}{c}10 \\
(25.6 \%) \\
\end{array}$ & $\begin{array}{c}9 \\
(23.2 \%) \\
\end{array}$ & $\begin{array}{c}7 \\
(17.9 \%) \\
\end{array}$ & $\begin{array}{c}39 \\
(100 \%) \\
\end{array}$ & 0 \\
\hline & $\mathrm{P} 12$ & $\begin{array}{c}0 \\
(0 \%) \\
\end{array}$ & $\begin{array}{c}1 \\
(10 \%) \\
\end{array}$ & $\begin{array}{c}2 \\
(20 \%) \\
\end{array}$ & $\begin{array}{c}2 \\
(20 \%) \\
\end{array}$ & $\begin{array}{c}5 \\
(50 \%) \\
\end{array}$ & $\begin{array}{c}10 \\
(100 \%) \\
\end{array}$ & 1 \\
\hline \multirow{2}{*}{$\begin{array}{l}\text { Cell phones are used by students for } \\
\text { malpractices in tests or exams. }\end{array}$} & L13 & $\begin{array}{c}3 \\
(7.7 \%) \\
\end{array}$ & $\begin{array}{c}5 \\
(12.8 \%) \\
\end{array}$ & $\begin{array}{c}9 \\
(23.1 \%) \\
\end{array}$ & $\begin{array}{c}17 \\
(43.6 \%) \\
\end{array}$ & $\begin{array}{c}5 \\
(12.8 \%) \\
\end{array}$ & $\begin{array}{c}39 \\
(100 \%) \\
\end{array}$ & 0 \\
\hline & $\mathrm{P} 13$ & $\begin{array}{c}1 \\
(9.1 \%)\end{array}$ & $\begin{array}{c}1 \\
(9.1 \%)\end{array}$ & $\begin{array}{c}3 \\
(27.3 \%)\end{array}$ & $\begin{array}{c}3 \\
(27.3 \%)\end{array}$ & $\begin{array}{c}3 \\
(27.3 \%)\end{array}$ & $\begin{array}{c}11 \\
(100 \%)\end{array}$ & 0 \\
\hline \multirow{2}{*}{$\begin{array}{l}\text { Students lose focus and attention due to their } \\
\text { cell phone use in classroom. }\end{array}$} & L14 & $\begin{array}{c}2 \\
(5.1 \%)\end{array}$ & $\begin{array}{c}6 \\
(15.4 \%) \\
\end{array}$ & $\begin{array}{c}2 \\
(5.1 \%)\end{array}$ & $\begin{array}{c}22 \\
(56.5 \%)\end{array}$ & $\begin{array}{c}7 \\
(17.9 \%)\end{array}$ & $\begin{array}{c}39 \\
(100 \%)\end{array}$ & 0 \\
\hline & P14 & $\begin{array}{c}0 \\
(0 \%) \\
\end{array}$ & $\begin{array}{c}1 \\
(9.1 \%)\end{array}$ & $\begin{array}{c}1 \\
(9.1 \%)\end{array}$ & $\begin{array}{c}4 \\
(36.4 \%) \\
\end{array}$ & $\begin{array}{c}5 \\
(45.6 \%) \\
\end{array}$ & $\begin{array}{c}11 \\
(100 \%)\end{array}$ & 0 \\
\hline \multirow{2}{*}{$\begin{array}{l}\text { Cell phones should be banned during the lecture } \\
\text { hours. }\end{array}$} & L15 & $\begin{array}{c}4 \\
(10.3 \%) \\
\end{array}$ & $\begin{array}{c}11 \\
(28.2 \%) \\
\end{array}$ & $\begin{array}{c}2 \\
(5.1 \%) \\
\end{array}$ & $\begin{array}{c}9 \\
(23.1 \%) \\
\end{array}$ & $\begin{array}{c}13 \\
(33.3 \%) \\
\end{array}$ & $\begin{array}{c}39 \\
(100 \%) \\
\end{array}$ & 0 \\
\hline & P15 & $\begin{array}{c}1 \\
(9 \%) \\
\end{array}$ & $\begin{array}{c}2 \\
(18.2 \%) \\
\end{array}$ & $\begin{array}{c}3 \\
(27.3 \%) \\
\end{array}$ & $\begin{array}{c}2 \\
(18.2 \%) \\
\end{array}$ & $\begin{array}{c}3 \\
(27.3 \%) \\
\end{array}$ & $\begin{array}{c}11 \\
(100 \%) \\
\end{array}$ & 0 \\
\hline
\end{tabular}

Where $\mathrm{SD}=$ Strongly Disagree, $\mathrm{D}=$ Disagree, $\mathrm{NO}=$ No Opinion, $\mathrm{A}=$ Agree, $\mathrm{SA}=$ Strongly Agree and $\mathrm{N}=$ Total Attended. 


\subsection{Lecturers' Perceptions on Students' Phubbing in University Classroom}

It was observed from table 1 that $53.8 \%$ of the lecturers agreed and $23.1 \%$ of them strongly agreed that students did not switch off or keep their cell phones in silent mode during lecture hours (statement L1). While $20.5 \%$ of the lecturers disagreed, $2.6 \%$ of them were uncertain. Around $27.3 \%$ of the PAL Tutors agreed and another $27.3 \%$ of them strongly agreed on statement P1. While $9 \%$ of the PAL Tutors strongly disagreed, $18.2 \%$ of them disagreed. About $18.2 \%$ of them were uncertain.

It can be seen that $41 \%$ of the lecturers agreed and another $41 \%$ of them strongly agreed that the whole class and the lecturers were interrupted when cell phones rang in the classroom (statement L2). While 2.6\% of the lecturers strongly disagreed, $7.7 \%$ of them disagreed on statement L2. Around $7.7 \%$ of them did not have any opinion. More than one third of the PAL Tutors (36.4\%) agreed and more than half of them (54.5\%) strongly agreed on statement $\mathrm{P} 2$. About $9.1 \%$ of them disagreed.

It was observed that $33.3 \%$ of the lecturers agreed and $38.5 \%$ of them strongly agreed that they did not allow students to attend phone calls in classroom (statement L3). About $2.6 \%$ of the lecturers strongly disagreed and $20.5 \%$ of them disagreed. Around $5.1 \%$ of them were indeterminate. While $18.2 \%$ of the PAL Tutors agreed and $9.1 \%$ of them strongly agreed on statement P3, $9.1 \%$ of them strongly disagreed and $27.3 \%$ of them disagreed. Around $36.3 \%$ of them were uncertain.

Statement L4 revealed that $43.6 \%$ of the lecturers agreed and $20.5 \%$ of them strongly agreed that they gave permission to students to leave the classroom and attend the calls if it was an emergency (statement L4). About $15.4 \%$ of the lecturers strongly disagreed and $5.1 \%$ of them disagreed on statement L4. Around $15.4 \%$ of them were indeterminate. While $54.5 \%$ of the PAL Tutors agreed and $36.4 \%$ of them strongly agreed on statement $\mathrm{P} 4,9.1 \%$ of them did not have any opinion.

It emerged that $53.9 \%$ of the lecturers agreed and $7.7 \%$ of them strongly agreed that students' text during lecture time (statement L5). While $5.1 \%$ of the lecturers strongly disagreed and $17.9 \%$ of them disagreed on statement L5, $15.4 \%$ of them were uncertain. Around $27.3 \%$ of the PAL Tutors agreed and $45.4 \%$ of them strongly agreed on statement P5. However, $27.3 \%$ of them disagreed.

It can be seen that $10.3 \%$ of the lecturers agreed that students made calls during lecture time (statement L6) and $5.1 \%$ of them did not have any opinion. Around $41 \%$ of the lecturers strongly disagreed and $43.6 \%$ of them disagreed on statement L6. While $33.3 \%$ of the PAL Tutors agreed on P6, another $33.3 \%$ of them did not have any opinion. Around $11.2 \%$ of the PAL Tutors strongly disagreed, $22.2 \%$ of them disagreed on statement P6 and two of them did not attend.

It was clear that $20.5 \%$ of the lecturers agreed and $2.5 \%$ of them strongly agreed that students played games on cell phones during lecture period (statement L7). About 15.4\% of the lecturers strongly disagreed and $38.5 \%$ of them disagreed on statement L7. Around $23.1 \%$ of them preferred a neutral stance. Around $18.2 \%$ of the PAL Tutors agreed and $36.4 \%$ of them did not have any opinion on statement P7. While $27.3 \%$ of the PAL Tutors strongly disagreed, $18.1 \%$ of them disagreed on statement P7.

Statement L8 revealed that $41 \%$ of the lecturers agreed and $15.4 \%$ of them strongly agreed that students had a temptation to be connected to social networking sites such as Facebook, Twitter and Youtube during the lecture time (statement L8). About $7.7 \%$ of the lecturers strongly disagreed and $15.4 \%$ of them disagreed on statement L8. Around $20.5 \%$ of them were indeterminate. While $27.3 \%$ of the PAL Tutors agreed and $54.5 \%$ of them strongly agreed on statement P8, $18.2 \%$ of them disagreed.

Almost three quarters $(71.8 \%)$ of the lecturers agreed and $17.9 \%$ of them strongly agreed that students were distracted when their classmates used cell phones in the class room (statement L9). Around $2.6 \%$ of the lecturers strongly disagreed and $7.7 \%$ of them did not have any opinion on statement L9. More than half (54.5\%) of the PAL Tutors agreed and more than one third $(36.4 \%)$ of them strongly agreed on statement P9. However, 9.1\% of them were indeterminate.

More than half (51.3\%) of the lecturers agreed and one quarter of them $(25.6 \%)$ strongly agreed that students immediately used their cell phones whenever the lecturer gave them a small break (statement L10). While 5.1\% of the lecturers strongly disagreed and $7.7 \%$ of them disagreed on statement L10, $10.3 \%$ of them were uncertain. Around $36.4 \%$ of the PAL Tutors agreed and $54.5 \%$ of them strongly agreed on statement P10. About $9.1 \%$ of them were uncertain.

It emerged that $36.8 \%$ of the lecturers agreed and another $36.8 \%$ of them strongly agreed that they felt students were addicted to cell phones (statement L11). While $13.2 \%$ of the lecturers strongly disagreed and 5.3\% of them disagreed on statement L11, 7.9\% of them did not have any opinion. One lecturer did not attend. Almost two third $(63.6 \%)$ of the PAL Tutors strongly agreed and $18.2 \%$ of them agreed on statement P11. About $9.1 \%$ of the PAL Tutors strongly disagreed and another $9.1 \%$ of them did not have any opinion.

It can be seen that $23.2 \%$ of the lecturers agreed and $17.9 \%$ of them strongly agreed that the students were lazy to write notes after they started using cell phones (statement L12). While $5.1 \%$ of the lecturers strongly disagreed, $28.2 \%$ of them disagreed on statement L12. Around $25.6 \%$ of them did not have any opinion. About $20 \%$ of the PAL Tutors agreed and half of them $(50 \%)$ strongly agreed on statement P12. About $10 \%$ of them disagreed and $20 \%$ of them did not have any opinion. One PAL Tutors did not attend.

It was observed that $43.6 \%$ of the lecturers agreed and 
$12.8 \%$ of them strongly agreed that cell phones were used by students for malpractices in tests or exams (statement L13). About $7.7 \%$ of the lecturers strongly disagreed and $12.8 \%$ of them disagreed. Around $23.1 \%$ of them were indeterminate. While $27.3 \%$ of the PAL Tutors agreed and another $27.3 \%$ of them strongly agreed on statement P13, $9.1 \%$ of them strongly disagreed and another $9.1 \%$ of them disagreed. Around $27.3 \%$ of them were uncertain.

Statement L14 revealed that more than half $(56.5 \%)$ of the lecturers agreed and $17.9 \%$ of them strongly agreed that students lost focus and attention due to their cell phone use in classroom (statement L14). About 5.1\% of the lecturers strongly disagreed and $15.4 \%$ of them disagreed on statement L14. Around $5.1 \%$ of them were indeterminate. More than one third $(36.4 \%)$ of the PAL Tutors agreed and almost half $(45.6 \%)$ of them strongly agreed on statement P14. Around $9.1 \%$ of them disagreed and another $9.1 \%$ of them did not have any opinion.

Around $23.1 \%$ of the lecturers agreed and one third $(33.3 \%)$ of them strongly agreed that cell phones should be banned during the lecture hours (statement L15). While $10.3 \%$ of the lecturers strongly disagreed and $28.2 \%$ of them disagreed on statement L15, 5.1\% of them preferred a neutral stance. About $18.2 \%$ of the PAL Tutors agreed and $27.3 \%$ of them strongly agreed on statement P15. While $9 \%$ of the PAL Tutors strongly disagreed and $18.2 \%$ of them disagreed, $27.3 \%$ of them preferred a neutral stance.

\subsection{Lecturers' Perceptions on the Percentage of Students' Phubbing in Classroom}

It was observed from Table 2 that majority (82.1\%) of the lecturers responded that $(0 \%-20 \%)$ of the students played games on cell phones during lecture period (statement A_L1). While $12.8 \%$ of the lecturers responded that $(21 \%-40 \%)$ of the students did statement A_L1, 5.1\% of them responded that $(41 \%-60 \%)$ of the students did statement A_L1. Almost two quarter (63.6\%) of the PAL Tutors responded that $(0 \%-20 \%)$ of the students did statement A_P1. Around $18.2 \%$ of the PAL Tutors responded that $(21 \%-40 \%)$ of the students did statement A_P1. While $9.1 \%$ of the PAL Tutors responded that $(41 \%-60 \%)$ of the students did statement A_P1, another group of $9.1 \%$ of them responded that $(61 \%-80 \%)$ of the students did statement A_P1.

Statement A_L2 revealed that more than half (51.3\%) of the lecturers responded that $(0 \%-20 \%)$ of the students texted during lecture period. More than one quarter $(25.6 \%)$ of the lecturers responded that $(21 \%-40 \%)$ of the students did statement A_L2. About $17.9 \%$ of the lecturers responded that $(41 \%-60 \%)$ of the students did statement A_L2. While $2.6 \%$ of the lecturers responded that $(61 \%-80 \%)$ of the students did statement A_L2, another group of $2.6 \%$ of them responded that $(81 \%$ $100 \%$ ) of the students did statement A_L2. Around $18.2 \%$ of the PAL Tutors responded that $(0 \%-20 \%)$ of the students did statement A_P2. While $45.4 \%$ of the PAL Tutors responded that $(41 \%-60 \%)$ of the students did statement A_P2, $27.3 \%$ of them responded that $(61 \%$ $80 \%$ ) of the students did statement A_P2 and $9.1 \%$ of them responded that $(81 \%-100 \%)$ of the students did statement A_P2.

More than half $(53.8 \%)$ of the lecturers responded that $(0 \%-20 \%)$ of the students engaged in social network sites such as facebook, twitter and youtube during lecture time (statement A_L3). One quarter $(25.6 \%)$ of the lecturers responded that $(21 \%-40 \%)$ of the students did statement A_L3. Around $17.9 \%$ of the lecturers responded that (41\%-60\%) of the students did statement A_L3. While $2.6 \%$ of the lecturers responded that $(61 \%-80 \%)$ of the students did statement A_L3, another $2.6 \%$ of them responded that $(81 \%-100 \%)$ of the students did statement A_L3. About $18.2 \%$ of the PAL Tutors responded that $(0 \%-20 \%)$ of the students did statement A_P3 and another $18.2 \%$ of them responded that $(21 \%-40 \%)$ of the students did statement A_P3. While $18.2 \%$ of the PAL Tutors responded that $(41 \%-60 \%)$ of the students did statement A_P3 and $36.3 \%$ of them responded that $(61 \%$ $80 \%$ ) of the students did statement A_P3, only $9.1 \%$ of the PAL Tutors responded that $(81 \%-100 \%)$ of the students did statement A_P3. 
Table 2. Triangulation of descriptive statistics of lecturers' perceptions on students' phubbing in university classroom

\begin{tabular}{|c|c|c|c|c|c|c|c|}
\hline $\begin{array}{c}\text { STATEMENT } \\
\text { How many students }\end{array}$ & $\#$ & $0 \%-20 \%$ & $21 \%-40 \%$ & $41 \%-60 \%$ & $61 \%-80 \%$ & $81 \%-100 \%$ & $\mathbf{N}$ \\
\hline \multirow{2}{*}{$\begin{array}{l}\text { play games on cell phones } \\
\text { during your lecture period? }\end{array}$} & A_L1 & $\begin{array}{c}32 \\
(82.1 \%) \\
\end{array}$ & $\begin{array}{c}5 \\
(12.8 \%) \\
\end{array}$ & $\begin{array}{c}2 \\
(5.1 \%) \\
\end{array}$ & $\begin{array}{c}0 \\
(0 \%) \\
\end{array}$ & $\begin{array}{c}0 \\
(0 \%) \\
\end{array}$ & $\begin{array}{c}39 \\
(100 \%) \\
\end{array}$ \\
\hline & A_P1 & $\begin{array}{c}7 \\
(63.6 \%) \\
\end{array}$ & $\begin{array}{c}2 \\
(18.2 \%)\end{array}$ & $\begin{array}{c}1 \\
(9.1 \%)\end{array}$ & $\begin{array}{c}1 \\
(9.1 \%)\end{array}$ & $\begin{array}{c}0 \\
(0 \%)\end{array}$ & $\begin{array}{c}11 \\
(100 \%)\end{array}$ \\
\hline \multirow{2}{*}{$\begin{array}{l}\text { text during your lecture } \\
\text { period? }\end{array}$} & A_L2 & $\begin{array}{c}20 \\
(51.3 \%) \\
\end{array}$ & $\begin{array}{c}10 \\
(25.6 \%) \\
\end{array}$ & $\begin{array}{c}7 \\
(17.9 \%) \\
\end{array}$ & $\begin{array}{c}1 \\
(2.6 \%) \\
\end{array}$ & $\begin{array}{c}1 \\
(2.6 \%) \\
\end{array}$ & $\begin{array}{c}39 \\
(100 \%) \\
\end{array}$ \\
\hline & A_P2 & $\begin{array}{c}2 \\
(18.2 \%) \\
\end{array}$ & $\begin{array}{c}0 \\
(0 \%) \\
\end{array}$ & $\begin{array}{c}5 \\
(45.4 \%) \\
\end{array}$ & $\begin{array}{c}3 \\
(27.3 \%) \\
\end{array}$ & $\begin{array}{c}1 \\
(9.1 \%) \\
\end{array}$ & $\begin{array}{c}11 \\
(100 \%)\end{array}$ \\
\hline \multirow{2}{*}{$\begin{array}{l}\text { engage in social network } \\
\text { sites such as facebook, } \\
\text { twitter and youtube during } \\
\text { the lecture time? }\end{array}$} & A_L3 & $\begin{array}{c}21 \\
(53.8 \%) \\
\end{array}$ & $\begin{array}{c}9 \\
(23.1 \%) \\
\end{array}$ & $\begin{array}{c}7 \\
(17.9 \%) \\
\end{array}$ & $\begin{array}{c}1 \\
(2.6 \%) \\
\end{array}$ & $\begin{array}{c}1 \\
(2.6 \%) \\
\end{array}$ & $\begin{array}{c}39 \\
(100 \%) \\
\end{array}$ \\
\hline & A_P3 & $\begin{array}{c}2 \\
(18.2 \%) \\
\end{array}$ & $\begin{array}{c}2 \\
(18.2 \%) \\
\end{array}$ & $\begin{array}{c}2 \\
(18.2 \%) \\
\end{array}$ & $\begin{array}{c}4 \\
(36.3 \%) \\
\end{array}$ & $\begin{array}{c}1 \\
(9.1 \%) \\
\end{array}$ & $\begin{array}{c}11 \\
(100 \%)\end{array}$ \\
\hline \multirow{2}{*}{$\begin{array}{l}\text { use their cell phones } \\
\text { immediately whenever you } \\
\text { give them a small break? }\end{array}$} & A_L4 & $\begin{array}{c}10 \\
(25.6 \%) \\
\end{array}$ & $\begin{array}{c}4 \\
(10.3 \%) \\
\end{array}$ & $\begin{array}{c}9 \\
(23.1 \%) \\
\end{array}$ & $\begin{array}{c}10 \\
(25.6 \%) \\
\end{array}$ & $\begin{array}{c}6 \\
(15.4 \%) \\
\end{array}$ & $\begin{array}{c}39 \\
(100 \%) \\
\end{array}$ \\
\hline & A_P4 & $\begin{array}{c}1 \\
(9.1 \%)\end{array}$ & $\begin{array}{c}0 \\
(0 \%) \\
\end{array}$ & $\begin{array}{c}2 \\
(18.2 \%)\end{array}$ & $\begin{array}{c}4 \\
(36.3 \%) \\
\end{array}$ & $\begin{array}{c}4 \\
(36.4 \%) \\
\end{array}$ & $\begin{array}{c}11 \\
(100 \%)\end{array}$ \\
\hline \multirow{2}{*}{ are addicted to cell phones? } & A_L5 & $\begin{array}{c}9 \\
(23.1 \%)\end{array}$ & $\begin{array}{c}5 \\
(12.8 \%) \\
\end{array}$ & $\begin{array}{c}5 \\
(12.8 \%) \\
\end{array}$ & $\begin{array}{c}11 \\
(28.2 \%)\end{array}$ & $\begin{array}{c}9 \\
(23.1 \%) \\
\end{array}$ & $\begin{array}{c}39 \\
(100 \%) \\
\end{array}$ \\
\hline & A_P5 & $\begin{array}{c}1 \\
(9.1 \%) \\
\end{array}$ & $\begin{array}{c}1 \\
(9.1 \%) \\
\end{array}$ & $\begin{array}{c}2 \\
(18.2 \%) \\
\end{array}$ & $\begin{array}{c}4 \\
(36.3 \%) \\
\end{array}$ & $\begin{array}{c}3 \\
(27.3 \%) \\
\end{array}$ & $\begin{array}{c}11 \\
(100 \%) \\
\end{array}$ \\
\hline \multirow{2}{*}{$\begin{array}{c}\text { are lazy to write notes after } \\
\text { they started using cell } \\
\text { phones? }\end{array}$} & A_L6 & $\begin{array}{c}18 \\
(46.1 \%) \\
\end{array}$ & $\begin{array}{c}8 \\
(20.5 \%) \\
\end{array}$ & $\begin{array}{c}4 \\
(10.3 \%) \\
\end{array}$ & $\begin{array}{c}5 \\
(12.8 \%) \\
\end{array}$ & $\begin{array}{c}4 \\
(10.3 \%) \\
\end{array}$ & $\begin{array}{c}39 \\
(100 \%) \\
\end{array}$ \\
\hline & A_P6 & $\begin{array}{c}1 \\
(9.1 \%) \\
\end{array}$ & $\begin{array}{c}1 \\
(9.1 \%) \\
\end{array}$ & $\begin{array}{c}4 \\
(36.3 \%) \\
\end{array}$ & $\begin{array}{c}3 \\
(27.3 \%) \\
\end{array}$ & $\begin{array}{c}2 \\
(18.2 \%) \\
\end{array}$ & $\begin{array}{c}11 \\
(100 \%) \\
\end{array}$ \\
\hline
\end{tabular}

Where $\mathrm{N}=$ Total Attended.

It emerged that $25.6 \%$ of the lecturers responded that $(0 \%-20 \%)$ of the students used their cell phones immediately whenever they got a small break (statement A_L4). About $10.3 \%$ of the lecturers responded that $(21 \%$ - $40 \%$ ) of the students did statement A_L4 and $23.1 \%$ of the lecturers responded that $(41 \%-60 \%)$ of the students did statement A_L4. A quarter $(25.6 \%)$ of the lecturers responded that $(\overline{6} 1 \%-80 \%)$ of the students did statement A_L4. Around $15.4 \%$ of the lecturers responded that $(81 \%$ - 100\%) of the students did statement A_L4. While 9.1\% of the PAL Tutors responded that $(0 \%-20 \%)$ of the students did statement A P4, 18.2\% of the PAL Tutors responded that $(41 \%-60 \%)$ of the students did statement A_P4. More than one third $(36.3 \%)$ of PAL Tutors responded that $(61 \%-80 \%)$ of the students did statement A_P4 and $36.4 \%$ of them responded that $(81 \%-100 \%)$ of the students did statement A_P4.

Almost one quarter $(23.1 \%)$ of the lecturers responded that $(0 \%-20 \%)$ of the students were addicted to cell phones (statement A_L5). While $12.8 \%$ of them lecturers responded that $(21 \%-40 \%)$ of the students did statement A_L5, another $12.8 \%$ of them responded that $(41 \%-60 \%)$ of the students did statement A_L5. About $28.2 \%$ of the lecturers responded that $(61 \%-80 \%)$ of the students did statement A_L5 and $23.1 \%$ of them responded that $(81 \%$ $100 \%$ ) of the students did statement A_L5. While $9.1 \%$ of the PAL Tutors responded that $(0 \%-20 \%)$ of the students did statement A_P5 and another $9.1 \%$ of them responded that $(21 \%-40 \%)$ of the students did statement A_P5. Around $18.2 \%$ of the PAL Tutors responded that (41\%-60\%) of the students did statement A_P5 and 36.3\% of them responded that $(61 \%-80 \%)$ of the students did statement A_P5. More than one quarter (27.3\%) of the PAL Tutors responded that $(81 \%-100 \%)$ of the students did statement A_P5.

Furthermore, it can be seen that $46.1 \%$ of the lecturers responded that $(0 \%-20 \%)$ of the students were lazy to write notes after they started using cell phones (statement A_L6). Around $20.5 \%$ of the lecturers responded that $(21 \%-40 \%)$ of the students did statement A_L6 and $10.3 \%$ of them responded that $(41 \%-60 \%)$ of the students did statement A_L6. While $12.8 \%$ of the lecturers responded that $(61 \%-80 \%)$ of the students did statement A_L6, $10.3 \%$ of them responded that $(81 \%-100 \%)$ of the students did statement A_L6.In the case of PAL Tutors, while $9.1 \%$ of the them responded that $(0 \%-20 \%)$ of the students did statement A_P6 and another $9.1 \%$ of them responded that $(21 \%-40 \%)$ of the students did statement A_P6. More than one third (36.3\%) of the PAL Tutors responded that $(41 \%-60 \%)$ of the students did statement A_P6. More than one quarter (27.3\%) of PAL Tutors responded that $(61 \%-80 \%)$ of the students did statement A_P6 and $18.2 \%$ of them responded that $(81 \%$ $100 \%$ ) of the students did statement A_P6.

\section{Discussion}

The study established that students did not switch off or kept their cell phones in silent mode during the lecture hours. Shrivastava and Shrivastava [25, p. 640] concurred "most of the time teachers have to ask the students to 
switch off or keep in silent mode". On the other hand, Hammer, et al. [31] highlighted that majority of the students indicated that their cell phones were on quiet mode during the class hours. Findings of the present study are therefore consistent with issues raised by Shrivastava and Shrivastava [25] but contradictory with the findings by Hammer, et al. [31]. According to the views of researchers of the current study, students are more tempted to do some off-task behaviours using smartphones than to concentrate in the lecture.

The study further established that whole class, lecturers and PAL Tutors were interrupted when cell phones rang in the classroom. Nazir [28] stated that lecturers were distracted when the students' smartphones beeps or rings in the classroom. Campbell [32] reported that ringing was a serious source of distraction and interruption for both students and lecturers. Shrivastava and Shrivastava [25] had also observed that it was a serious interruption when cell phones ring during lecture hours. Findings of the current study are therefore similar to the views by Nazir [28], Campbell [32] and Shrivastava and Shrivastava [25]. Making interruptions while the lecture takes place shows that those students are not serious about their studies and they are disturbing the others students who want to concentrate in class.

It emerged from the study that lecturers and PAL Tutors gave permission to students to leave the classroom and attend the calls if it is an emergency. Hammer, et al. [31] and Synnott [33] indicated that students left the classroom to attend calls. Therefore, the finding of the current study is consistent with the finding by Hammer, et al. [31] and Synnott [33]. This attitude of allowing students to excuse from the class to attend the calls helps to continue the lecture without interruptions.

In the present study, it showed that students' texted during lecture time. Mtega, Bernard, Msungu and Sanare [34] and Synnott [33] averred that students used cell phones to send text messages during the lecture period. Therefore, finding of the present study is consistent with the views by Mtega, Bernard, Msungu and Sanare [34] and Synnott [33]. As per the view of researchers, students who are texting while the lecture takes place show that they are addicted to smart phones.

Majority of the participants indicated that students did not play games on cell phones during lecture period. This finding is consistent with the finding by Matto and Kazungu [35] who averred that students never played games on their mobile phones during the lecture time. However, the finding of the current study contradicts with the findings by Gilroy [36] who stated that university students in the United States of America played games on their cell phones while lecture was taking place. According to the view of the researchers of the current study, this attitude of students could be because that they are not interested in playing games on cell phone.

The results of this study showed that students have a temptation to be connected to social networking sites such as Facebook, Twitter and Youtube during lecture time. Synnott [33] indicated that students used cell phones to visit social networking sites. Nazir [28] averred that students were highly tempted to use smartphones at least once during the lecture hours either to surf the internet or check Whatsapp or use social networking sites. Finding of this study coincided with the results by Synnott [33] and Nazir [28]. Social networking is the most common activity that people of all ages does now. However, doing such activities in the classroom is a serious issue which is not acceptable.

A vast majority of the participants indicated that students were distracted when their classmates used cell phones in the classroom. Using of cell phones in the classroom not only distracts the class but also lead to poor academic performance [25]. Matto and Kazungu [35] stressed that uncontrolled phone uses distract class periods and lectures. Finding of the current study concurs with the views by Shrivastava and Shrivastava [25] and Matto and Kazungu [35]. A strict rule of not to use smartphones in classroom will help to avoid this problem.

The study revealed that students immediately used their cell phones whenever lecturers and PAL Tutors gave them a small break. This result is inconsistent with the finding by Fernandez [37] who stated that students did not have any pressure to attend incoming calls or reply to new messages. Using of cell phone immediately when they get a break time shows that they have high level of temptation and pressure to use cell phone.

The current research showed that students were addicted to cell phones. Matto and Kazungu [35] also had a same view that students were spending much of their valuable time on cell phones than on studies due to their addiction towards cell phones. Similarly, Sarwar and Soomro [38] indicated in their study that majority of the adolescents were addicted to their smartphones. Therefore, finding of current study is in line with the findings by Matto and Kazungu [35] and Sarwar and Soomro [38]. The researchers of the current study view that addiction on smartphones not only affects students' academic performance but also their personality.

The study found that students used cell phones for malpractices in tests or exams. Shrivastava and Shrivastava $[25$, p. 640$]$ stated that "approximately all respondents agreed that use of mobile phone is a potential source of cheating during exam". Synnott [33] had also observed that students use cell phones during exams for malpractices. Matto and Kazungu [35] stated that use of cell phones aided students to cheat during exams. Therefore, finding of the current study is in parallel with the findings by Shrivastava and Shrivastava [25], Matto and Kazungu [35] and Synnott [33]. If a fine is charged by the management to the students who are doing such off-task behaviours, it may help to avoid this malpractice to a greater extent. 
The present study established that students lost focus and attention due to their cell phone use in classroom. Shrivastava and Shrivastava [25] shared a similar view when they state that use of cell phones in classroom while studying causes the main reason for the lack of concentration. Implementing Closed-Circuit Television (CCTV) cameras in all classrooms will make the students to have a fear to use their smartphones in classroom.

Furthermore, majority of the lecturers and PAL Tutors suggested that cell phones should be banned during the lecture hours. Most of the teaching staff in a study conducted by Pulliam [39] also averred that students should not be allowed to use cell phones during class. The finding of the current study concurs with the finding by Pulliam [39]. Smartphones should be used only for educational purposes in classroom for the effective learning and teaching.

\section{Conclusions}

The study could be concluded from the findings that both lecturers and PAL Tutors had a negative perception on students' phubbing in classroom. Students lost focus on lecture as they were busy with texting and visiting social networking sites using their smart phones. They had a high temptation to use cell phones immediately when they get a break. It was strongly confirmed that students were addicted to cell phones. Around $0 \%-20 \%$ of the students were phubbing by doing different activities in classroom which is more enough for the whole learning and teaching to be spoiled. Overall, the results of the study showed that students' phubbing in university classroom created a serious interruption to the lecturers, PAL Tutors as well as distraction to the whole class and this implicated the current study to highlight that students were crossing the boundary line.

The sample size was not large enough. It would be more constructive to conduct a study to find the perception of students too and compare the perception of students, lecturers and PAL Tutors to find out the significant association between them.

The study recommends the following:

1. First and foremost, the university management must make a policy to allow students to use smartphones only for educational purposes. This will help to reduce students' phubbing in classroom to a certain extent.

2. Lecturers should be lenient if the student needs to use smartphones for any emergency or important matters.

3. CCTV cameras must be implemented in each classroom to monitor whether students are performing any off-task behaviors instead of using it for educational purposes.

4. A fine which is affordable for the students must be implemented as a punishment to reduce phubbing if the management notices the CCTV footages of any student phubbing in classroom.

The findings of this study can provide further research on comparing the perspective of lecturers on students' phubbing in universities with the perspective of teachers on learners' phubbing in schools.

\section{REFERENCES}

[1] "The mobile economy 2018", GSMA intelligence, https://www.gsmaintelligence.com/videos/mobile-econom y-2018/\#: :text=The $\% 20$ GSMA $\% 20$ Mobile $\% 20$ Economy \%20series,including\%20forecasts\%20out\%20to\%202025 (accessed February. 25, 2021).

[2] "The state of mobile internet connectivity", GSMA, https://www.gsma.com/r/wp-content/uploads/2020/09/GS MA-State-of-Mobile-Internet-Connectivity-Report-2020.p df (accessed February. 27, 2021).

[3] Writer S., "The state of South Africa's mobile market vs the rest of Africa", Businesstech, https://businesstech.co.za/ne ws/mobile/184693/the-state-of-south-africas-mobile-marke t-vs-the-rest-of-africa/ (accessed February. 28, 2021).

[4] Kemp S., "Digital 2020: South Africa", DataReportal, https://datareportal.com/reports/digital-2020-south-africa\#: $\sim:$ text $=$ There $\% 20$ were $\% 20103.5 \% 20$ million $\% 20$ mobile, 17 $6 \% 25 \% 20$ of $\% 20$ the $\% 20$ total\%20population (accessed February. 28, 2021).

[5] Beger G., \& Sinha A., "South African mobile generation: Study on South African young people on mobiles," unicef, pp.1-48, 2012.

[6] Howard, J., "When kids their first cell phones around the world", CNN, Retrieved from edition.cnn.com/2017/12/11 /health/cell-phones-for-kids-parenting-without-borders-exp lainer-intl/index.html (accessed February. 28, 2021).

[7] David M. E., Roberts J. A., Christenson B, "Too much of a good thing: Investigating the association between actual smartphone use and individual well-being". International Journal of Human-Computer Interaction, vol. 34, no. 3, pp. 265-275, 2017. DOI: https://doi.org/10.1080/10447318.20 17.1349250 .

[8] Bjornsen C. A., Poredoš M., Puklek Levpušček M., Zupančič M., Kavčič T., "Positive and negative social media use and personality traits across cultures," Poster presented at the 18th European Conference on Developmental Psychology, Utrecht, The Netherlands, August., 2017. https://www.worldcat.org/title/positive-and -negative-social-media-use-and-personality-traits-across-c ultures/oclc/1016093114\#borrow

[9] Switzer J. S., Switzer R. V., "The myth of the tech-savvy student: The role of media educators in a web 2.0 world," Journal of Media Education, vol. 4, no. 4, pp. 15-27, 2013.

[10] Thompson P., "The digital natives as learners: Technology use patterns and approaches to learning," Computers \& Education, vol. 65, pp. 12-33, 2013. DOI: 10.1016/j.compedu.2012.12.022 
[11] Salisbury L., Laincz J., Smith J.J., "Undergraduate ownership of small mobile devices: engagement and use in an academic environment," Science \& Technology Libraries, vol. 34, no. 1, pp. 91-107, 2015. DOI: $10.1080 / 0194262 X .2014 .999397$

[12] Junco R., Cotten, S. R., "No A 4 U: The relationship between multitasking and academic performance," Computers \& Education, vol. 59, pp. 505-514, 2012. DOI: 10.1016/j.compedu.2011.12.023

[13] Rosen L. D., Carrier L.M., Cheever N. A., "Facebook and texting made me do it: Media-induced task switching while studying," Computers in Human Behavior, vol. 29, no. 3, pp. 948-958, 2013. DOI: 10.1016/j.chb.2012.12.001

[14] Taneja A., Fiore V., Fischer B., "Cyber-slacking in the classroom: Potential for digital distraction in the new age," Computers \& Education, vol. 82, pp. 141-151, 2015. DOI: 10.1016/j.compedu.2014. 11.009

[15] Lawson D., Henderson B. B., "The Costs of Texting in the Classroom," College Teaching, 63 (3), 119-124, 2015. DOI: $10.1080 / 87567555.2015 .1019826$

[16] Junco, R., "Too much face and not enough books: The relationship between multiple indices of Facebook use and academic performance," Computers in Human Behavior, vol. 28, no. 1, pp. 187-198, 2012. DOI: 10.1016/j.chb.2011.08.026

[17] Lepp A., Barkley J. E., Karpinski A. C., "The relationship between cell phone use and academic performance in a sample of US college students," SAGE Open, vol. 5, no. 1, pp.1-9, 2015. DOI: $10.1177 \% 2$ F2158244015573169

[18] Wentworth D. K., Middleton J. H., "Technology use and academic performance," Computers \& Education, vol. 78, pp. 306-311, 2014. DOI: 10.1016/j.compedu.2014.06.012

[19] Ugur N. G., Koc T., "Time for Digital Detox: Misuse of Mobile Technology and Phubbing," Procedia - Social and Behavioral Sciences, vol. 195, pp. 1022-1031, 2015. DOI: 10.1016/j.sbspro.2015.06.491

[20] David M. E., Roberts J. A., "Phubbed and alone: Phone snubbing, social exclusion, and attachment to social media," Journal of the Association for Consumer Research, 2(2), 155-163, 2017. DOI: 10.1086/690940

[21] Roberts J. A., David, M. E., "My life has become a major distraction from my cell phone: Partner phubbing and relationship satisfaction among romantic partners," Computers in Human Behavior, vol. 54, pp. 134-141, 2016. DOI: $10.1016 /$ j.chb.2015.07.058

[22] Razzaq A., Samiha Y. T., Anshari M., "Smartphone Habits and Behaviors in Supporting Students Self-Efficacy," International Journal of Emerging Technologies in Learning, vol. 13, no. 2, pp. 94-109, 2018. DOI: 10.3991/ijet.v13i02.7685

[23] Burns S. M., Lohenry K., "Cellular phone use in class: implications for teaching and learning a pilot study," College Student Journal, vol. 44, no. 3, pp. 805-810, 2010 https://www.researchgate.net/profile/Kevin-Lohenry/publi cation/257114169_Cellular_Phone_Use_in_Class_Implica tions for Teaching and Learning - A Pilot Study/links/

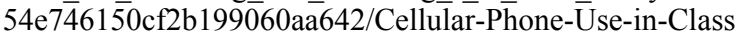
-Implications-for-Teaching-and-Learning-A-Pilot-Study.p df

[24] Ilic U., Tanyeri T., "Is phubbing a matter for educators: A case for pre-service and in-service teachers," Malaysian online journal of Education Technology, vol. 9, no. 1, pp. 70-79, 2021. DOI: 10.17220/mojet.2021.9.1.246

[25] Shrivastava A., Shrivastava M., "Classroom Distraction Due to Mobile Phones Usage by Students: College Teachers' Perceptions", International Journal of Computer and Information Technology, vol. 3, no. 3, pp. 638 - 642. 2014. doi: $10.1080 / 03634520600748573$

[26] Langmia K., Glass A., "Coping with Smart Phone 'Distractions' in a College Classroom", Teaching Journalism and Mass Communication, vol. 4, no. 1, pp. 13-23, 2014. https://aejmc.us/wp-content/uploads/sites/9/2 014/03/tjmc-w14-langmia-glass.pdf

[27] Bugeja M., "The Age of Distraction: The Professor or the Processor?," Futurist, vol. 42, no. 1, pp. 66-68, 2007. https://www.proquest.com/openview/1d983a7d40303e13d 6ae $56695 \mathrm{~d} 37 \mathrm{a} 82 \mathrm{~d} / 1$. pdf?pq-origsite $=$ gscholar $\& \mathrm{cbl}=47758$

[28] Nazir T., "Impact of classroom phubbing on teachers who face phubbing during lectures," Psychology Research on Education and Social Sciences, vol. 1, no. 1, pp. 41-47, 2020.https://dergipark.org.tr/en/download/article-file/1116 609

[29] Flanigan A. E., Kiewra A. K., "What College Instructors Can Do About Student Cyber-slacking," Educational Psychology Review, vol. 30, pp. 585-597, 2017. DOI: 10.1007/S10648-017-9418-2

[30] Ahmad T., "Mobile phones as a learning tool: a lecturer's viewpoint," Society and Business Review, vol. 13, no. 2, pp. 132-139. 2018. DOI: 0.1108/SBR-03-2018-0021.

[31] Hammer R., Ronen M., Sharon A., Lankry T., Huberman Y., Zamtsov V., "Mobile Culture in College Lectures: Instructors' and Students' Perspectives," Interdisciplinary Journal of E-Learning and Learning Objects, vol. 6. pp. 293-304, 2010. DOI: 10.28945/1316

[32] Campbell S., "Perceptions of mobile phones in college classrooms: Ringing, cheating, and classroom policies," Communication Education, vol. 55, no. 3, pp. 280-294, 2006. DOI: $10.1080 / 03634520600748573$

[33] Synnott C. K., "Smartphones in the classroom and students' Misperceptions: faculty development," Journal of Higher Education Management, vol. 33, no. 1, pp. 119-135. 2018. DOI: $10.2139 / \mathrm{ssrn} .3038013$

[34] Mtega W. P., Bernard R., Mungu A. C., Sanare R., "Using Mobile Phones for Teaching and Learning Purposes in Higher Learning," Proceedings and report of the 5th Ubuntu Net Alliance annual conference, Dar es salaam, Tanzania, 2012, pp. 118-129.https://www.researchgate.net/publicatio $\mathrm{n} / 275340682$ Using Mobile Phones for Teaching and Learning_Purposes in_Higher_Learning Institutions the Case_of_Sokoine_University_of_Agriculture_in_Tanzania

[35] Matto G., Kazungu I., "Mobile phone and chat apps usage among malawian university Students: Luanar's experience," Research Report Series (RRS), vol. 2, no. 1, pp. 73-85, 2018. https://www.academia.edu/36649552/Mobile_Phone and Chat_Apps_Usage_among_Malawian_University_Student s_LUANARs_Experience 
[36] Gilroy M., "Invasion of the classroom cell phones," Education Digest, vol. 69, no. 6, pp. 56-61, 2004. http://melparagg.pbworks.com/f/Gilroy+-+Invasion + of + Ce 11+Phones.pdf

[37] Fernandez S., "University Student's Perspectives on Using Cell Phones in Classrooms - Are They Dialing up Disaster?," The Turkish Online Journal of Educational Technology, vol. 17, no. 1, pp. 246-258, 2018 https://files.eric.ed.gov/fulltext/EJ1165729.pdf
[38] Sarwar M., Soomro T.R., "Impact of smartphone's on society," European Journal of Scientific Research, vol. 92, no. 2, $216-226, \quad 2013$. https://www.researchgate.net/publication/236669025 Impa ct_of_Smartphone's_on_Society

[39] Pulliam D., "Effect of Student Classroom Cell Phone Usage on Teachers," Masters Theses \& Specialist Projects. Western Kentucky University, 2017. 